\title{
ТЕОРЕТИЧНІ ТА ПРАКТИЧНІ АСПЕКТИ РЕАЛІЗАЦІЇ РОЗУМНОСТІ СТРОКІВ У ЦИВІЛЬНОМУ СУДОЧИНСТВІ
}

Мороз Д. А., Дяченко С. В.

у зв'язку зі стрімким розвитком суспільних відносин і прагненням держави врегулювати у правовому полі суспільні відносини виникають колізії щодо застосування різних норм права. Статтю «Теоретичні та практичні аспекти реалізації розумності строків у цивільному судочинстві» присвячено принципу розумності строків у цивільному судочинстві. Надано визначення поняття «розумний строк розгляду справи», його призначення, законодавче закріплення, наукові обгрунтування сутності розумного строку, проблеми та шляхи реалізації, а також проаналізовано практику Європейського суду з прав людини щодо дотримання принципу «розумного строку» розгляду справи судами. У статmі детально проаналізовано теоретичні та практичні проблеми, які виникають під час реалізаціі принципу «розумного строку» розгляду справи.

Ключові слова: «розумний строк», процесуальні строки, затягування цивільного процесу, недотримання належних строків, право на справедливий суд.

В связи со стремительным развитием общественных отношений и стремлением государства урегулировать в правовом поле общественные отношения возникают коллизии по применению различных норм права. Статья «Теоретические и практические аспекты реализации разумности сроков в гражданском судопроизводстве» посвящена принципам разумности сроков в гражданском судопроизводстве. Дано определение понятия «разумный срок рассмотрения дела", его назначение, законодательное закре пление, научные обоснования сущности «разумного срока», проблемы и пути реализации, а также проанолизирована практика Европейского суда по правам человека относительно соблюдения принципа «разумного срока» рассмотрения дела судами. B статье подробно проанализированы теоретические и практические проблемы, возникающие при реализации принципа «разумного срока» рассмотрения дела

Ключевые слова: «разумный срок», процессуальные сроки, затягивание гражданского процесса, несоблюдение надлежащих сроков, право на справедливый суд.

Due to the rapid development of social relations and the desire of the state to regulate social relations in the legal field, conflicts arise regarding the application of different rules of law. In addition, the analysis of the legal literature indicates that problematic issues related to the timing of civil cases, as well as issues of improving the efficiency of civil justice were not often the subject of a full and comprehensive civil procedural study, a large number of questions or at all have not been studied, or are highly debatable. The article "Theoretical and practical aspects of the implementation of the reasonableness of terms in civil proceedings" is devoted to the principle of reasonableness of terms in civil proceedings. It was defined the "reasonable term" of the case, its purpose, legislative consolidation, scientific substantiation of the essence of "reasonable term", problems and ways of realization, also the case-law of the European Court of Human Rights on the observance of the "reasonable time"

Мороз Д. А., Дяченко С. В., 2019 principle by the courts. The article analyzes in detail the theoretical and practical problems that arise during the implementation of the "reasonable time" principle of the case, which are as follows. Failure to comply with reasonable time limits is the most common ground for Ukraine to violate the right to a fair and open trial within a reasonable time by a court. Another major problem is that the changes made to the Civil Procedure Code of Ukraine, on the contrary, further increase the overall length of court proceedings and the settlement of civil cases. Another problem is that the legislator, although defining a "reasonable time" because of the term "sufficient time", but did not reveal the criteria for determining such "reasonableness". And the new procedure for settling a dispute with the participation of a judge before the start of the trial on the merits, which was fixed by the legislator in the CPC of Ukraine in the new wording contrary to the purpose for which they were introduced, because such changes, unfortunately, do not contribute to ensuring the timely consideration of disputes by the courts, but on the contrary the length of the proceedings is further delayed. The article also applied international human rights standards and analyzed case law. The following methods were used in the writing of the article: analytical, historical, comparative, integral, evaluation, abstraction.

Key words: "reasonable time", procedural time limits, delay in civil proceedings, failure to observe proper time limits, right to a fair trial.

Гарантоване статтею 55 Конституції України право кожногонасудовийзахистпередбачаєможливість особи, права, свободи чи інтереси якої порушені, невизнані або оспорені, отримати законне та обґрунтоване судове рішення впродовж встановленого законом строку [1].

На здійснення судочинства впливає багато факторів, серед них -законність, справедливість, публічність, доступність та оперативність. Саме своєчасність захисту прав, свобод та інтересів осіб, що беруть участь у справі, $є$ одним з найважливіших чинників, що визначає ефективність його здійснення.

Встановлення та дотримання процесуальних строків має одну з першочергових цілей для забезпечення ефективного судового захисту. Як показує практика, недотримання строків розгляду справ не тільки порушує права особи на захист, а й формує в неї негативне ставлення до судової системи та неповагу до права.

Актуальність дослідження проблеми «розумності» строків судового розгляду зумовлена не тільки триваючою судово-правовою реформою, але й великою кількістю справ щодо порушення Україною права особи на «розумний» розгляд її справи судом у практиці Європейського суду з прав людини (ЄСПЛ).

Практика Європейського суду з прав людини показує, що саме недотримання розумних строків розгляду справ $\epsilon$ найпоширенішою підставою для порушення Україною права на справедливий і відкритий розгляд справи упродовж розумного строку незалежним і безстороннім судом. 
Аналіз юридичної літератури свідчить про те, що проблемні питання, які стосуються строків розгляду цивільних справ, не так часто були самостійним об'єктом повного і всебічного цивільно-процесуального дослідження.

Питання своєчасності розгляду та вирішення цивільних справ привертало увагу багатьох учених. Вказані питання висвітлювалися в роботах таких учених: О.В. Андрійчука, Д.Д. Луспеника, І.В. Турчин- Кукаріної, С.Я. Фурси, О.В. Андрійчук, С.С. Бичкова, Є.В. Васьковського, Я.В. Грель, В.П. Грибанова, О.М. Єрмакова, В.В. Комарова, В.В. Рєзнікова, О.Я. Рогач, Н.Ю. Сакара, А.В. Смітюх, О.С. Фонова, Н.А. Шебанова, М.Й. Штефана, К.С. Юдельсона, А.В. Юдіна та інших.

Мета статті - ґрунтовний аналіз законодавства, що регулює принцип «розумного строку» розгляду справи, правильне його застосування національними судами та аналіз правової доктрини для висвітлення принципу «розумності строків».

Науковці по-різному визначають поняття процесуальних строків. М.О. Сорока вказує, що у судочинстві процесуальні строки виступають як часова форма процесуальних відносин з приводу відправлення правосуддя судом, а також як форма існування й розвитку суб'єктивних прав та обов'язків, які становлять зміст процесуальних відносин у зазначеній сфері [2].

3.І. Цибуленко вважає, що розумним слід вважати строк, який об'єктивно необхідний і можливий для виконання. Цю позицію підтримує і М.Ю. Челишев, він говорить, що зазначений строк варто розглядати як реальний строк, адже залежно від певних обставин його тривалість може бути різною [3].

Своєю чергою М.Й. Штефан розглядав процесуальні строки як період часу, визначений для здійснення процесуальних дій учасниками процесу і судом або іншими особами за вказівкою закону або за приписом суду [4].

Я.П. Зейкан визначає процесуальний строк як: встановлений законом або призначений судом проміжок часу, з яким процесуальні норми пов'язують можливість та необхідність вчинення конкретних процесуальних дій або настання певних правових наслідків [5].

Проблеми затягування цивільного процесу, а також його наслідки та способи запобігання можуть стати перспективним напрямом і інших наукових досліджень.

Варто звернути увагу і на проблеми, які виникають під час реалізації принципу «розумності строків» судового розгляду в цивільному судочинстві.

Відповідно до частини 1 статті 6 Конвенції про захист прав людини і основоположних свобод «кожен має право на справедливий і публічний розгляд його справи упродовж розумного строку незалежним і безстороннім органом, визначеним законом». У коментарі до положення частини 1 статті 6 Конвенції зазначається те, що строк розгляду справи судом включає в себе все провадження з моменту звернення до суду або у порядку попереднього розгляду справи до відповідного органу і до моменту виконання рішення [6].

Сутність зазначеного положення про «розумність строків» такого розгляду варто тлумачити як таку, що визначає і строки провадження в суді, і строки виконавчого провадження. Хоча такий принцип і законодавчо закріплений у нормах цивільного судочинства, насправді він фактично не реалізується.
Принцип розумності строків розгляду справи вперше судом був закріплений у редакції Цивільного процесуального кодексу України у 2017 році. Законодавець зобов'язав суд встановлювати розумні строки для вчинення процесуальних дій і закріпив у статті 121 Цивільного процесуального кодексу України (ЦПК) це поняття таким чином: «Суд має встановлювати розумні строки для вчинення процесуальних дій. Строк $\epsilon$ розумним, якщо він передбачає час, достатній з урахуванням обставин справи для вчинення процесуальної дії та відповідає завданню цивільного судочинства» [7].

Таким чином, сутність поняття «розумний строк» визначається через поняття «достатній строк», але без розкриття критеріїв визначення такої «розумності».

У попередній редакції статті 157 цПК України зазначалось, що суд розглядає справи протягом розумного строку, але не більше двох місяців з дня відкриття провадження у справі, а справи про поновлення на роботі, про стягнення аліментів - одного місяця. У статті 210 нової редакції цПК України передбачено, що суд має розпочати розгляд справи по суті не пізніше ніж через шістдесят днів з дня відкриття провадження у справі, а у разі подовження строку підготовчого провадження - не пізніше наступного дня з дня закінчення такого строку [7].

У новій редакції цПк України частиною 2 статті 189 передбачено підготовче провадження, яке починається з відкриття провадження у справі та закінчується закриттям підготовчого засідання, яке має бути проведене протягом шістдесяти днів з дня відкриття провадження у справі. В окремих випадках для належної підготовки справи для розгляду по суті цей строк може бути подовжений не більше ніж на тридцять днів за клопотанням однієї зі сторін або з ініціативи суду. У минулій редакції цПк України попереднє судове засідання мало було бути проведене протягом 10 днів з дня відкриття провадження у справі. 3 чого випливає, що цей строк збільшили з 10 до 60 днів [7].

Тобто до нової редакції цПК були внесені зміни, які ще більше призвели до затягування загального строку розгляду і вирішення цивільних справ у суді.

Отже, закріплені законодавцем процесуальні строки розгляду справ у цПК України у новій редакції та описане вище суперечить меті, заради якої вони запроваджувались, адже такі зміни, на жаль, не сприяють забезпеченню своєчасності розгляду спорів судами, а навпаки, ще більше затягують тривалість розгляду справ.

Вагоме місце під час реалізації гарантованого особі права на справедливий суд відіграє судова практика, зокрема, практика Європейського суду з прав людини (ЄСПЛ).

Так, як уже вище було зазначено, кожна цивільна справа має бути розглянута судом у встановлений процесуальним законом строк, який своєю чергою має бути розумним. Саме в практиці ЄСПЛ поняття «розумний строк судового розгляду» розроблено найдетальніше.

Нормативною основою для функціонування судової системи України та Європейського суду з прав людини $\epsilon$ Конвенція про захист прав людини та основоположних свобод.

Статистичний аналіз ЄСПЛ вказує на те, що кількість скарг, за якими було встановлено факти порушення державами права на справедливий суд, становить ледве не половину від загальної кількості справ проти держав-членів Ради Європи. Основною проблемою у цьому 
контексті $€$ суттєве затягування розгляду судами справ. Окрім того, частка справ, у яких ЄСПЛ було встановлено факт порушення Україною права на справедливий суд, $є$ найбільшою, приблизно 33\% від загальної кількості рішень, ухвалених проти України.

Для визначення тривалості розгляду справи в «розумні строки» варто насамперед визначити часові проміжки розгляду справи.

Відповідно, перебіг строку у цивільних справах відраховується з моменту відкриття провадження у справі, а в окремих випадках - з моменту виникнення в особи права на подання позову до суду.

У справі «Букхольд проти Німеччини» 1981 р. визначено, що строк розгляду охоплює розгляд справ у судах першої, апеляційної та касаційної інстанцій. Водночас розгляд справ у конституційних судах не має враховуватися [8, с. 67].

Щодо закінчення тривалості цього строку, то єдиної позиції ЄСПЛ висловлено не було. Під час вирішення цивільних справ ЄСПЛ зазначає, що виконання рішення слід розглядати як обов'язкову складову частину судового провадження.

Після встановлення часових рамок розгляду справ на національному рівні ЄСПЛ оцінює іï «розумність» крізь призму чи $\epsilon$ тривалість судочинства доцільною.

Європейський суд з прав людини розробив власні критерії розумності строків розгляду справи в суді. Як приклад можна навести рішення в справі «Саєнко та інші проти України», в яких Європейський суд констатував порушення Україною п. 1 ст. 6, ст. 13 Конвенції про захист прав людини та основоположних свобод, у зв'язку із великою тривалістю цивільних проваджень підкреслив, що розумність тривалості судового розгляду має оцінюватися з урахуванням таких критеріїв, як: складність справи, поведінка заявників і відповідних органів влади, а також важливість предмета спору для заявників [9].

Належна поведінка заявника, як критерій «розумності» строку розгляду справи, не має призводити до умисного затягування розгляду справи. Якщо ж затримка розгляду справи відбулась через заявника, то суд може визнати відсутність порушення ст. 6 Конвенції про захист прав людини та основоположних свобод. У справі «Чірикоста та Віола проти Італії» ЄСПЛ вирішив, що 15-річний строк розгляду не $\epsilon$ невиправданим, тому що заявники 17 разів зверталися з проханням про відстрочку процесу та не заперечували проти вимог іншої сторони, що висловлювались 6 разів, про відкладення розгляду справи [10].

Що стосується поведінки відповідних органів державної влади, то для дотримання «розумності» строків розгляду вона оцінюється значно жорсткіше. У справі «Аллене Де Рибемон проти Франції», розгляд якої здійснювався приблизно 11 років і 8 місяців, ЄСПЛ вказав на порушення вимоги «розумного строку судового розгляду» у тому, що судові органи неодноразово відмовляли заявнику задовольнити прохання надати йому доказ, який для нього був дуже важливим, що призвело до затримки судового розгляду більше ніж на 8 років [11].

Найчастішими прикладами недотримання належних строків у справах проти України $є$ :

- неодноразові направлення судами на новий розгляд;

- непроведення судових засідань протягом тривалого часу;

- незастосування заходів примусу до осіб, які не з'являються на призначене засідання та багато інших прикладів.

Для механізмів швидкого розгляду судових справ вітчизняній судовій системі варто брати приклад з Європейського суду з прав людини. Адже, враховуючи велике завантаження, ЄСПЛ не побоявся змінити регламент та спростив окремі процедури, впровадивши використання прискорених процедур розгляду незначних чи неоскаржуваних справ.

Відповідальність за додержання національними судами розумних строків розгляду справ покладається на державу. Передбачення в бюджетному фінансуванні витрат на виконання присуджених Україні компенсацій на користь заявників, що призвело до порушення розумних строків розгляду справи, слугуватиме гарантією реального виконання рішень Європейського суду з прав людини.

Отже, судам необхідно враховувати запровадження розумних строків розгляду справи і розглядати справи у розумний для кожного індивідуального випадку строк, при цьому орієнтиром не завжди має бути встановлений граничний строк, визначений процесуальними нормами.

Тому доцільно з урахуванням європейських стандартів забезпечити право на справедливий суд та закріпити у законодавстві критерії (межі) визначення розумного строку, з урахуванням характеру спірних відносин та іï значення для сторін, поведінки інших учасників справи.

Важливість та необхідність подальшого удосконалення цивільного процесуального законодавства $\epsilon$ одним із найголовніших завдань сучасної правової спільноти, оскільки досконалий механізм відновлення справедливості $\epsilon$ запорукою гармонійного і стабільного існування та розвитку сучасного суспільства. 


\section{Проблеми цивільного та господарського права}

\section{Література}

1. Конституція України. Відомості Верховної Ради України (BBP). 2019. URL: https: //zakon.rada.gov.ua/laws/show/.

2. Сорока М.О. Поняття «процесуальний строк» в адміністративному судочинстві. Актуальні проблеми державного управління. № 1. 2010 р. С. 229-235. URL: http://nbuv.gov.ua/UJRN/apdy_2010_1_33.

3. Цибуленко 3.І. Зобов' язання зберігання в радянському цивільному праві. Вид-во Сарат. ун-ту, 2014 р. С. 141 .

4. Штефан М.Й. Цивільне процесуальне право України: академічний курс : підручник для студентів юридичних спеціальностей вищих навчальних закладів. Вид. дім «Н Юре», 2005 р. Бібліогр. С. 613-622.

5. Зейкан Я.П. Захист у кримінальній справі. Київ : KHT, 2006 р. С. 600.

6. Конвенція про захист прав людини і основоположних свобод 2013. URL: https://zakon.rada.gov.ua/laws/ show/995_004.

7. Цивільний процесуальний кодекс України. Відомості Верховної Ради України (ВВР). 19.10.2019. URL: https://zakon.rada.gov.ua/laws/show/1618-15.

8. Туманов В.А. Європейський суд 3 прав людини. Нарис організації та діяльності. Москва : Вид-во Норма, 2014 p. C. 304.
9. Судове рішення у справі ЄСПЛ № $39167 / 08$ «аєнко та інші проти України" від 23.03.2017 року. URL: http: / /sc.gov.ua/uploads/tinymce/files / Саєнко\%20та\% 20інші\%20проти\%20України.pdf.

10. Судове рішення у справі ЄСПЛ №5/1995/511/594 «Чірікоста та Віола проти Італї̈, від 21.11. 1995 року. URL: $\quad$ hudoc.echr.coe.int/app/conversion/pdf/library=/ XVIOLA\%20v.

11. Судове рішення у справі ЄСПЛ № 15175/89 «Аллене Де Рибемон проти Франції» від 10.02.1995 року. URL: http://search.ligazakon.ua/__doc2.nsf/link1/SO001116. html.

Мороз Д. А., студентка 4 курсу Навчально-наукового інституту права Університету державної фіскальної служби України

Дяченко С. В., кандидат юридичних наук, доцент кафедри цивільного права та процесу університету державної фіскальної служби України 